\title{
PENGARUH KONSEP DIRI DAN SELF EFFICACY MAHASISWA JURUSAN AKUNTANSI TERHADAP PRESTASI BELAJAR MAHASISWA JURUSAN AKUNTANSI (STUDI PADA UNIVERSITAS SAM RATULANGI)
}

\author{
Stevi Wuniarto ${ }^{1}$, Hendrik Manossoh ${ }^{2}$, Lidia M. Mawikere ${ }^{3}$ \\ 1,2,3 Jurusan Akuntansi, Fakultas Ekonomi dan Bisnis, Universitas Sam Ratulangi, Jl. Kampus Bahu, Manado, \\ 95115, Indonesia \\ E-mail : steviwun@gmail.com
}

\begin{abstract}
Achievement in learning is the result of the learning process that is determined by students individually in a certain time frame. The results of learning achievement are different for everyone, and are recorded as a score in your report card or in the achievement index. Learning achievement of a person is influenced by two factors, internal (from the individual) and external (outside of the individual), where the individual factor is more influential that the external factor, so the writer of this research have decided to emphasized more on the internal factors which are the self concept and self efficacy. The purpose of this research is to determine the influence of self concept and self efficacy on Majoring Accounting student towards their learning achievements. This research uses the survey method to collect prime data from a population of Majoring Accounting student from the University of Sam Ratulangi and also uses the determination of sample based on purposive sampling method. This research uses multiple linear regression analysis tools with the help of SPSS 22. The result of the research are, (1) Self concept has a significant influence on student learning achievement, (2) Self efficacy has a significant influence on student study prestige.

Keywords: Self Concept, Self Efficacy, Learning Achievement
\end{abstract}

\section{PENDAHULUAN}

Prestasi belajar merupakan hal yang penting bagi semua pihak, sebagai contoh : bagi peserta didik dan penyedia lapangan pekerjaan. Bagi peserta didik, prestasi digunakan sebagai salah satu bentuk pembuktian atas potensi yang dimiliki. Hal ini mendukung persaingan antara individu dan penyelenggaraan pendidikan guna mendapatkan prestasi belajar yang lebih baik. Sedangkan bagi penyedia lapangan pekerjaan, prestasi belajar peserta didik menjadi suatu tanda atas kemampuan seseorang dalam bekerja sehingga tak heran penyedia lapangan pekerjaan akan memilih pekerja yang mempunyai hasil belajar yang baik. Prestasi belajar adalah ukuran keberhasilan yang diperoleh mahasiswa selama proses belajarnya. Konsep diri dan self efficacy merupakan salah satu faktor internal yang dilahirkan dari tiap pribadi mahasiswa itu sendiri. Kedua faktor ini merupakan faktor pendukung dalam memperoleh hasil yang baik, dalam kaitannya dengan hasil prestasi belajar mahasiswa dengan indeks prestasi kumlatif (IPK) sebagai indikatornya. Sebagai mahasiswa, prestasi belajar menjadi idaman, sebagai bentuk kepuasan atas prestasi capaian selama mengikuti perkuliahan.

\section{LANDASAN TEORI}

Pengertian Akuntansi. Akuntansi merupakan proses identifikasi, pengukuran, dan pelaporan informasi keuangan, yang digunakan untuk membantu pemakai laporan keungan dalam menilai dan membuat keputusan yang jelas dan tegas (Zakiyudin, $2013: 2$ ). 
Akuntansi Manajemen. Pengertian akuntansi manajemen adalah proses analisis, identifikasi, pengukuran, penafsiran, penyusunan, dan komunikasi informasi yang dipakai pihak manajemen sebagai alat pengambilan keputusan (Simamora, $2012: 1$ ).

Akuntansi Keperilakuan. Pengertian akuntansi keperilakuan adalah ilmu yang mempelajari keterkaitan antara sistem akuntansi dan perilaku manusia dimana diakui keberadaannya (Suartana, $2010: 1$ ).

Konsep Diri. Pengertian konsep diri ialah perasaan atau pandangan mengenai diri sendiri (Rakhmat, 2015 : 98).

Self Efficacy. Menurut Ghufron (2014 : 77) self efficacy adalah keyakinan seseorang akan kemampuannya dalam mengatasi masalah.

Prestasi Belajar. Definisi prestasi belajar ialah memperoleh hasil dari kegiatan pembelajaran yang diakui berupa raport (Septina, $2016: 166$ ).

Penelitian Terdahulu. Beberapa referensi penelitian terdahulu yaitu : Rukoyah (2013), mengenai Pengaruh Self Efficacy dan Motivasi Belajar terhadap Prestasi Belajar, mendapatkan hasil motivasi belajar dan self efficacy mempunyai pengaruh positif terhadap prestasi belajar. dan Suryade (2014), mengenai Pengaruh Konsep Diri terhadap Prestasi Belajar, menunjukkan bahwa konsep diri mempunyai pengaruh positif terhadap prestasi belajar. Putri (2016), mengenai Pengaruh Konsep Diri dan Kedisiplinan Belajar terhadap Prestasi Belajar, menunjukkan bahwa kedisiplinan belajar dan konsep diri mempunyai pengaruh positif pada prestasi belajar.

\subsection{Kerangka Pemikiran}

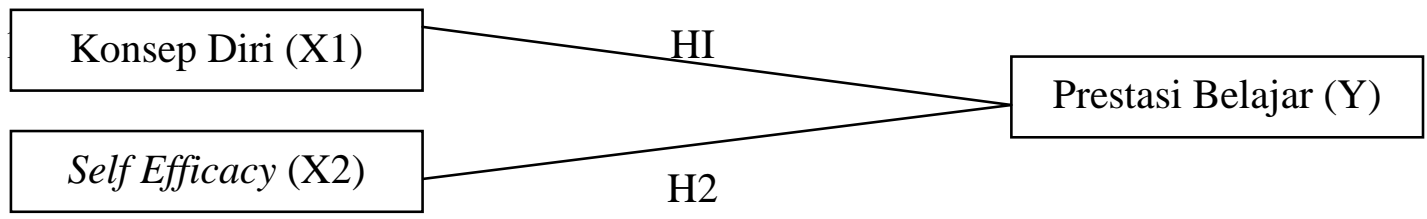

\subsection{Hipotesis Penelitian}

Dari hasil teori dan kerangka pemikiran, maka hipotesis sebagai berikut :

$\mathrm{H}_{1}$ : Konsep diri mahasiswa jurusan akuntansi berpengaruh signifikan positif terhadap prestasi belajar mahasiswa jurusan akuntansi.

$\mathrm{H}_{2}$ : Self efficacy mahasiswa jurusan akuntansi berpengaruh signifikan positif terhadap prestasi belajar mahasiswa jurusan akuntansi.

\section{METODE PENELITIAN}

Jenis Penelitian dan Sumber Data. Menggunakan jenis penelitian kuantitatif dalam penelitian ini. Sumber data menggunakan data primer.

Tempat dan Waktu Penelitian. Universitas Sam Ratulangi merupakan tempat penelitian dalam penelitian ini. Waktu penelitian dibuat pada bulan Juli 2018 hingga selesai.

Populasi dan Sampel. Pada Penelitian ini populasinya adalah mahasiswa jurusan akuntansi Universitas Sam Ratulangi. Sedangkan sampel pada penelitian ini memiliki jumlah 40 orang mahasiswa jurusan akuntansi. Teknik pengambilan sampel dari penelitian ini adalah Purposive Sampling, Adapun karakteristik sampel :

1. Merupakan mahasiswa jurusan akuntansi Universitas Sam Ratulangi, dengan tujuan untuk menjadikan mahasiswa menjadi seorang akuntan yang profesional.

2. Merupakan mahasiswa tingkat akhir, minimal sudah semester 8 atau lebih dengan asumsi mereka sudah menyelesaikan pembelajaran mata kuliah dibidang akuntansi. 


\section{Metode Analisis Data}

Pengujian Kualitas data. Uji validitas dan uji reabilitas dilakukan untuk menguji sejauh mana data yang diuji telah valid dan reliabel.

\section{Pengujian Asumsi Klasik}

a. Uji Normalitas. Suatu data berdistribusi normal atau tidak dilihat dari persamaan regresi yang dihasilkan pada uji normalitas.

b. Uji Multikolinearitas. Untuk menguji apakah terdapat hubungan antar variabel bebas pada model regresi.

c. Uji Heteroskedastisitas. Apakah terjadi ketidaksamaan variance antara residual suatu pengujian dengan pengujian lainnya dilihat dari uji heteroskedastisitas.

Analisis Regresi Linear Berganda. Kegunaan regresi linear berganda untuk memprediksi turun naiknya variabel terikat, jika dua variabel bebas atau lebih sebagai faktor yang nilainya dinaikturunkan (Sugiyono, 2016).

\section{Pengujian Hipotesis}

a. Uji t. Untuk mengetahui berapa besar pengaruh dari suatu variabel bebas dalam menjelaskan variabel terikat.

b. Uji F. Untuk mengetahui apakah variabel independen mempengaruhi variabel dependen (Ghozali, 2016 : 96).

c. Koefisien Determinasi $\left(\mathbf{R}^{2}\right)$. Untuk mengukur persentase variabel bebas dapat menjelaskan variabel terikat (Ghozali, 2013 : 197).

\section{Definisi Operasional}

Konsep Diri. Untuk mengukur konsep diri meliputi 5 indikator yaitu : (1) mampu mengatasi masalah; (2) menempatkan diri setara dengan orang lain; (3) mampu menerima pujian tanpa rasa malu; (4) mempunyai berbagai perasaan, perilaku, dan keinginan yang tidak seluruhnya disetujui oleh masyarakat; (5) mampu berusaha memperbaiki diri.

Self Efficacy.Untuk mengukur self efficacy meliputi 3 indikator yaitu : (1) tingkat kesulitan (level); (2) tingkat kekuatan (strength); (3) generalisasi (generality)

Prestasi Belajar. Untuk mengukur prestasi belajar yaitu dengan menggunakan IPK.

\section{HASIL PENELITIAN DAN PEMBAHASAN}

\subsection{Hasil Penelitian}

Deskripsi Umum Responden Penelitian

Tabel 1. Komposisi Responden Berdasarkan Jenis Kelamin

\begin{tabular}{ccc}
\hline Jenis Kelamin & Total & Presentase \\
\hline Pria & 10 & $25 \%$ \\
Wanita & 30 & $75 \%$ \\
Total & 40 & $100 \%$ \\
\hline
\end{tabular}

(Sumber : Hasil Olahan, 2018)

Tabel 2. Komposisi Responden Berdasarkan IPK

\begin{tabular}{ccc}
\hline IPK & Total & Presentase \\
\hline $2,00-2,49$ & 0 & $0 \%$ \\
$2,50-2,99$ & 4 & $10 \%$ \\
$3,00-3,49$ & 20 & $50 \%$ \\
$3,50-4,00$ & 16 & $40 \%$ \\
Total & 40 & $100 \%$ \\
\hline
\end{tabular}

(Sumber : Hasil Olahan, 2018) 


\section{Hasil Uji Kualitas Data}

a. Uji Validitas

Tabel 3. Hasil Uji Validitas Variabel Konsep Diri

\begin{tabular}{cccc}
\hline Pertanyaan & $\begin{array}{c}\text { Corrected item total correlation } \\
\text { (r hitung) }\end{array}$ & r tabel & VALIDITAS \\
\hline 1 & 0,612 & 0,312 & Valid \\
2 & 0,612 & 0,312 & Valid \\
3 & 0,672 & 0,312 & Valid \\
4 & 0,406 & 0,312 & Valid \\
5 & 0,389 & 0,312 & Valid \\
6 & 0,579 & 0,312 & Valid \\
7 & 0,520 & 0,312 & Valid \\
8 & 0,327 & 0,312 & Valid \\
9 & 0,791 & 0,312 & Valid \\
10 & 0,537 & 0,312 & Valid \\
11 & 0,594 & 0,312 & Valid \\
12 & 0,607 & 0,312 & Valid \\
\hline
\end{tabular}

(Sumber : Output Pengolahan SPSS, 2018)

Tabel 4. Hasil Uji Validitas Variabel Self Efficacy

\begin{tabular}{cccc}
\hline Pertanyaan & $\begin{array}{c}\text { Corrected item total correlation } \\
\text { (r hitung) }\end{array}$ & r tabel & VALIDITAS \\
\hline 1 & 0,342 & 0,312 & Valid \\
2 & 0,605 & 0,312 & Valid \\
3 & 0,506 & 0,312 & Valid \\
4 & 0,497 & 0,312 & Valid \\
5 & 0,451 & 0,312 & Valid \\
6 & 0,401 & 0,312 & Valid \\
7 & 0,513 & 0,312 & Valid \\
8 & 0,375 & 0,312 & Valid \\
9 & 0,602 & 0,312 & Valid \\
10 & 0,559 & 0,312 & Valid \\
11 & 0,588 & 0,312 & Valid \\
12 & 0,551 & 0,312 & Valid \\
\hline
\end{tabular}

(Sumber : Output Pengolahan SPSS, 2018)

\section{b. Uji Reliabilitas}

Tabel 5. Uji Reliabilitas

\begin{tabular}{ccc}
\hline Variabel & Cronbach's Alpha & Keterangan \\
\hline Konsep Diri & 0,728 & Reliabel \\
Self Efficacy & 0,710 & Reliabel \\
\hline
\end{tabular}

(Sumber : Output Pengolahan SPSS, 2018) 


\section{Hasil Uji Asumsi Klasik}

\section{a. Uji Normalitas}

\section{Tabel 6. One-Sample Kolmogorov-Smirnov Test}

\begin{tabular}{llr}
\hline & & Unstandardized Residual \\
\hline Normal Parameters & & 40 \\
& Mean & 0.0000000 \\
Most Extreme Differences & Std. Deviation & 0.48345739 \\
& Absolute & 0.094 \\
& Positive & 0.094 \\
Test Statistic & Negative & -0.087 \\
Asymp. Sig. (2-tailed) & & 0.094 \\
\hline
\end{tabular}

(Sumber : Output Pengolahan SPSS, 2018)

Hasil tabel diatas memperoleh nilai Asymp.sig sebesar 0,20. Maka dapat dilihat bahwa nilai Asymp.sig > 0,05 jadi disimpulkan data berdistribusi normal.

\section{b. Uji Multikolinieritas}

Tabel 7. Coefficients ${ }^{a}$

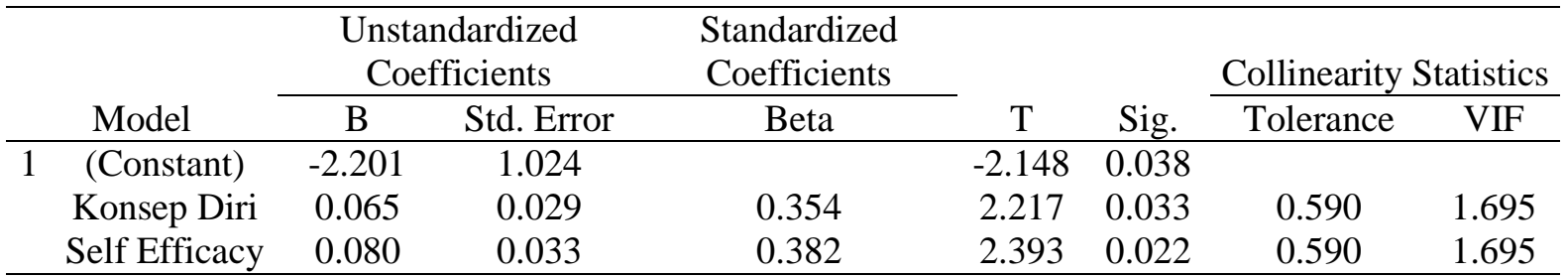

a. Dependent Variable: Prestasi Belajar

(Sumber : Output Pengolahan SPSS, 2018)

Berdasarkan tabel diatas Konsep Diri dan Self Efficacy memiliki nilai tolerance 0,590 $>0,1$ dan nilai VIF $1,695<10$, maka dapat dilihat bahwa variabel bebas memiliki nilai tolerance $>0,1$ dan nilai $\mathrm{VIF}<10$. jadi disimpulkan tidak mengalami multikolineritas.

\section{c. Uji Heteroskedastisitas}

Tabel 8. Coefficients ${ }^{a}$

\begin{tabular}{|c|c|c|c|c|c|c|}
\hline & \multirow[b]{2}{*}{ Model } & \multicolumn{2}{|c|}{$\begin{array}{c}\text { Unstandardized } \\
\text { Coefficients }\end{array}$} & $\begin{array}{c}\text { Standardize } \\
\text { d } \\
\text { Coefficients }\end{array}$ & \multirow[b]{2}{*}{$\mathrm{T}$} & \\
\hline & & $\mathrm{B}$ & Std. Error & Beta & & Sig. \\
\hline 1 & (Constant) & 0.647 & 0.625 & & 1.034 & 0.308 \\
\hline & Konsep Diri & 0.004 & 0.018 & 0.052 & 0.242 & 0.810 \\
\hline & $\begin{array}{c}\text { Self } \\
\text { Efficacy }\end{array}$ & -0.011 & 0.020 & -0.118 & -0.554 & 0.583 \\
\hline
\end{tabular}

a. Dependent Variable: RES2

(Sumber : Output Pengolahan SPSS, 2018)

Berdasarkan hasil uji glesjer diperoleh signifikansi Konsep Diri dengan nilai 0,810>0,05, dan signifikansi Self Efficacy dengan nilai 0,583 > 0,05, maka dapat disimpulkan Konsep Diri dan Self Efficacy tidak terjadi heteroskedastisitas pada model regresi. 


\section{Regresi Linear Berganda}

Tabel 9. Coefficients ${ }^{\mathrm{a}}$

\begin{tabular}{|c|c|c|c|c|c|c|}
\hline & \multirow[b]{2}{*}{ Model } & \multicolumn{2}{|c|}{$\begin{array}{c}\text { Unstandardized } \\
\text { Coefficients }\end{array}$} & \multirow{2}{*}{$\begin{array}{c}\begin{array}{l}\text { Standardized } \\
\text { Coefficients }\end{array} \\
\text { Beta } \\
\end{array}$} & \multirow[b]{2}{*}{$\mathrm{t}$} & \multirow[b]{2}{*}{ Sig. } \\
\hline & & B & Std. Error & & & \\
\hline \multirow[t]{3}{*}{1} & (Constant) & -2.201 & 1.024 & & -2.148 & 0.038 \\
\hline & $\begin{array}{c}\text { Konsep Diri } \\
\text { (X1) }\end{array}$ & 0.065 & 0.029 & 0.354 & 2.217 & 0.033 \\
\hline & $\begin{array}{c}\text { Self Efficacy } \\
\text { (X2) }\end{array}$ & 0.080 & 0.033 & 0.382 & 2.393 & 0.022 \\
\hline
\end{tabular}

a. Dependent Variable: Prestasi Belajar (Y)

(Sumber : Output Pengolahan SPSS, 2018)

Hasil analisis dapat disusun model persamaan regresi linear berganda sebagai berikut :

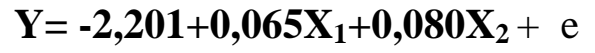

Dari persamaan diatas dapat diinterpretasikan sebagai berikut :

1. Konstanta (a) : $-2,201$, nilai konstanta bernilai negatif artinya jika skor variabel konsep diri dan self efficacy dianggap tidak ada, maka skor prestasi belajar mahasiswa jurusan akuntansi akan semakin berkurang.

2. Konsep diri $\left(\mathrm{X}_{1}\right): 0,065$, koefisien variabel konsep diri bernilai positif artinya pengaruh konsep diri terhadap prestasi belajar mahasiswa jurusan akuntansi adalah bersifat positif.

3. Self efficacy $\left(\mathrm{X}_{2}\right)$ : 0,080, koefisien variabel Self efficacy bernilai positif artinya pengaruh. Self efficacy terhadap prestasi belajar mahasiswa jurusan akuntansi adalah bersifat positif.

\section{Pengujian Hipotesis}

\section{a. Uji t}

Tabel 10. Coefficients ${ }^{\mathrm{a}}$

\begin{tabular}{|c|c|c|c|c|c|c|}
\hline & \multirow[b]{2}{*}{ Model } & \multicolumn{2}{|c|}{$\begin{array}{l}\text { Unstandardized } \\
\text { Coefficients }\end{array}$} & \multirow{2}{*}{$\begin{array}{c}\begin{array}{c}\text { Standardized } \\
\text { Coefficients }\end{array} \\
\text { Beta } \\
\end{array}$} & \multirow[b]{2}{*}{$\mathrm{T}$} & \multirow[b]{2}{*}{ Sig. } \\
\hline & & $\mathrm{B}$ & Std. Error & & & \\
\hline \multirow[t]{3}{*}{1} & (Constant) & -2.201 & 1.024 & & -2.148 & 0.038 \\
\hline & $\begin{array}{l}\text { Konsep Diri } \\
\text { (X1) }\end{array}$ & 0.065 & 0.029 & 0.354 & 2.217 & 0.033 \\
\hline & $\begin{array}{c}\text { Self Efficacy } \\
\text { (X2) }\end{array}$ & 0.080 & 0.033 & 0.382 & 2.393 & 0.022 \\
\hline
\end{tabular}

a. Dependent Variable: Prestasi Belajar (Y)

(Sumber : Output Pengolahan SPSS, 2018)

Untuk menentukan $\mathrm{t}_{\text {tabel }}$ memakai : $\mathrm{df}=\mathrm{n}-\mathrm{k}-1(\mathrm{df}=40-2-1=37)$, maka dihasilkan nilai $\mathrm{t}_{\text {tabel }}$ sebesar 2,026. Tabel diatas dapat dilihat nilai signifikan dari konstanta 0,038. Dari tabel diatas juga dapat diketahui bahwa hasil dari uji t adalah sebagai berikut.

1. $\mathrm{H}_{1}$ : Konsep diri menunjukkan nilai $\mathrm{t}_{\text {hitung }}$ sebesar 2,217 $>\mathrm{t}_{\text {tabel }}$ sebesar 2,026 dengan signifikansi (sig) sebesar 0,033 < 0,050 maka $\mathrm{Ha}_{1}$ diterima, yang berarti $\mathrm{Ho}_{1}$ ditolak. Hal ini berarti konsep diri berpengaruh positif signifikan terhadap prestasi belajar mahasiswa jurusan akuntansi.

2. $\mathrm{H}_{2}$ : Self efficacy menunjukkan nilai $\mathrm{t}_{\text {hitung }}$ sebesar 2,393 $>\mathrm{t}_{\text {tabel }}$ sebesar 2,026 dengan signifikansi (sig) sebesar 0,022 < 0,050 maka $\mathrm{Ha}_{2}$ diterima, yang berarti $\mathrm{Ho}_{2}$ ditolak. Hal ini berarti Self efficacy berpengaruh positif signifikan terhadap prestasi belajar mahasiswa jurusan akuntansi 
b. Uji F (Uji Simultan)

Tingkat signifikansi dalam penelitian ini yaitu 0,05 dengan pengujian dua arah (2tailed) dan nilai $\mathrm{F}_{\text {tabel }}$ untuk $\mathrm{n}=40$ dan $\mathrm{k}=2$ maka $\mathrm{df}=38$ yaitu 3,24 .

Tabel 11. ANOVA

\begin{tabular}{ccrrrrr}
\hline & & Sum of & & & & \\
& Model & Squares & Df & Mean Square & F & \multicolumn{2}{c}{ Sig. } \\
\hline 1 & Regression & 7.284 & 2 & 3.642 & 14.784 & $0.000^{\mathrm{b}}$ \\
& Residual & 9.116 & 37 & 0.246 & & \\
& Total & 16.400 & 39 & & & \\
\hline
\end{tabular}

(Sumber : Output Pengolahan SPSS, 2018)

Hasil regresi secara simultan, maka didapat nilai $F_{\text {hitung }}$ sebesar $14,784>$ nilai $F_{\text {tabel }}$ sebesar 3,24 dan nilai signifikansi 0,000 < 0,05. Dari hasil tersebut menyimpulkan konsep diri dan self efficacy mempunyai pengaruh sugnifikan terhadap prestasi belajar mahasiswa jurusan akuntansi maka $\mathrm{H} 3$ diterima karena $F_{\text {hitung }}>F_{\text {tabel }}$ dan tingkat signifikansi $<0,05$.

\section{c. Koefisien Determinan $\left(\mathbf{R}^{2}\right)$}

Tabel 12. Model Summary

\begin{tabular}{crrrr}
\hline Model & R & R Square & Adjusted R Square & Std. Error of the Estimate \\
\hline 1 & $0.666^{\mathrm{a}}$ & 0.444 & 0.414 & 0.49635 \\
\hline
\end{tabular}

a. Predictors: (Constant), Self Efficacy (X2), Konsep Diri (X1)

Sumber : Output Pengolahan SPSS, 2018

Hasil dari pengujian ini, diperoleh koefisien determinasi memiliki nilai R Square sebesar 0,444. Maka kemampuan variabel independen yaitu konsep diri dan self efficacy dalam menjelaskan variasi dari variabel dependen yaitu prestasi belajar mahasiswa jurusan akuntansi sebesar $44,4 \%$ dan sisanya 43,6\% tidak dibahas dalam penelitian ini karena dipengaruhi oleh faktor-faktor lainnya.

\subsection{Pembahasan}

Hasil uji yaitu konsep diri mahasiswa jurusan akuntansi berpengaruh signifikan terhadap prestasi belajar mahasiswa jurusan akuntansi, konsep diri mahasiswa jurusan akuntansi memiliki nilai $t_{\text {hitung }} 2,217>2,026$ dan tingkat signifikansi $0,000<0,05$. Maka Ha diterima sesuai dengan hasil uji hipotesis. Berdasarkan hasil penelitian diketahui self efficacy mahasiswa jurusan akuntansi berpengaruh signifikan terhadap prestasi belajar mahasiswa jurusan akuntansi, self efficacy memiliki nilai thitung 2,393>2,026 dan tingkat signifikansi $0,022<0,05$. Maka $\mathrm{Ha}_{2}$ diterima sesuai dengan hasil uji hipotesis.

\section{KESIMPULAN DAN SARAN}

\subsection{Kesimpulan}

1. Konsep diri mahasiswa jurusan akuntansi $\left(\mathrm{X}_{1}\right)$ berpengaruh signifikan terhadap prestasi belajar mahasiswa jurusan akuntansi. Dengan nilai $t_{\text {hitung }}$ sebesar 2,217 $>t_{\text {tabel }}$ sebesar 2,026 dengan signifikansi (sig) sebesar $0,033<0,050$.

2. Self efficacy mahasiswa jurusan akuntansi (X2) berpengaruh signifikan terhadap prestasi belajar mahasiswa jurusan akuntansi. Dengan nilai $t_{\text {hitung }}$ sebesar 2,393 $>t_{\text {tabel }}$ sebesar 2,026 dengan signifikansi (sig) sebesar 0,022 <0,050.

\subsection{Saran}

Adapun saran-saran sebagai berikut : Bagi mahasiswa, khususnya subyek dalam penelitian ini yakni mahasiswa jurusan akuntansi Universitas Sam Ratulangi supaya bisa mengenali dan memahami konsep diri dan self efficacynya masing-masing sehingga bisa meningkatkan prestasi belajar dengan sebaik-baiknya. Bagi pihak fakultas, diharapkan bisa 
memberikan fasilitas dan SDM yang baik sehingga mahasiswa bisa meningkatkan prestasinya dengan se-maksimal mungkin. Bagi peneliti selanjutnya, diharapkan ada penelitian kelanjutan sehingga bisa berkembang ilmu dan penelitian ini.

\section{DAFTAR PUSTAKA}

Ghozali, Imam. 2013. Aplikasi Analisis Multivariate Dengan Program IBM SPSS 23. Badan Penerbit Universitas Diponegoro, Semarang.

Ghozali, Imam. 2016. Aplikasi Analisis Multivariate Dengan Program IBM SPSS 23. Badan Penerbit Universitas Diponegoro, Semarang.

Ghufron, Nur dan Rini Risnawati. 2014. Teori-Teori Psikologi. Ar-Ruzz Media, Yogyakarta. Rakmat, Jalaludin. 2015. Psikologi Komunikasi. Edisi II. Remaja Rosda Karya, Bandung.

Rukoyah, Yoyoh Siti. 2013. Pengaruh Self Efficacy dan Motivasi Belajar Terhadap Prestasi Belajar pada Mata Pelajaran Akuntansi. Skripsi. Universitas Pendidikan Indonesia Bandung.

Septiana, A. 2016. Hubungan Gaya Belajar dan Persepsi Siswa Tentang Metode Mengajar Guru Terhadap Prestasi Belajar matematika pada Siswa-siswi Kelas XI SMA Negeri 1 Sangatta Utara Kutai Timur. Jurnal Psikologi, 4(2).

Simamora, Henry. 2012. Akuntansi Manajemen, Edisi Ketiga. Star Gate Publisher, Riau.

Suartana, I Wayan. 2010. Akuntansi Keperilakuan Teori dan Implementasi. CV Andi OFFSET, Yogyakarta.

Sugiyono. 2016. Metode Penelitian Kuantitatif, Kualitatif dan R\&D. PT Alfabet, Bandung.

Suryade, Sagita. 2014. Pengaruh Konsep Diri Terhadap Prestasi Belajar Siswa pada Mata Pelajaran Ekonomi di Sekolah Menengah Atas Negeri 1 Ujungbatu Kabupaten Rokan Hulu. Skripsi. Universitas Islam Negeri Sultan Syarif Kasim Riau Pekan Baru.

Putri, Aninda Sandhi. 2016. Pengaruh Konsep Diri dan Kedisiplinan Belajar Terhadap Prestasi Belajar pada Siswa Kelas VIII SMP N 2 Gamping Sleman Tahun Ajaran 2015/2016. Skripsi. Universitas PGRI Yogyakarta.

Zakiyudin, A. 2013. Akuntansi Tingkat Dasar Dilengkapi Dengan Akuntansi Bagi Organisasi Pengelola Zakat. Mitra Wacana Media, Jakarta. 